УДК 025.355]:026:37]](477-25)

Коваленко Світлана Георгї̈вна, науковий співробітник Державної науковопедагогічної бібліотеки України імені В. О.Сухомлинського, м. Київ, e-mail: skovalenko@yandex.ru

\title{
СТВОРЕННЯ АВТОРИТЕТНОГО ФАЙЛУ „ІНДИВІДУАЛЬНІ АВТОРИ” НА БАЗІ АБІС „ІРБІС” ДЛЯ ЕЛЕКТРОННОГО КАТАЛОГУ ДЕРЖАВНОЇ НАУКОВО-ПЕДАГОГІЧНОЇ БІБЛІОТЕКИ УКРАЇНИ ІМЕНІ
}

\section{В. О. СУХОМЛИНСЬКОГО}

\begin{abstract}
Анотація
Ступінь стандартизації під час формування основних полів бібліографічних записів, у тому числі пошукових полів, є одним з основних показників якості масивів бібліографічної інформації. В умовах окремих бібліотек завдання стандартизації розв’язується шляхом створення різноманітних довідників, що містять нормативну інформацію, використовувану в певній бібліотеці - нормативні бази даних. Для багатьох книгозбірень такими нормативними базами слугують бази авторитетних файлів. Здійснення роботи зі стандартизації під час формування бібліографічних записів називається авторитетним контролем.

У статті висвітлено питання створення авторитетних файлів для електронного каталогу в Державній науково-педагогічній бібліотеці України імені В. О. Сухомлинського, уточнено поняття „авторитетний контроль”, розкрито технологію створення авторитетного файлу „Індивідуальні автори”.

Ключові слова: електронні каталоги, авторитетні файли, індивідуальні автори, бібліотеки, інформаційні ресурси, бібліотечні каталоги, авторитетні записи.

Одним 3 основних показників якості масивів бібліографічної інформації, створеної з використанням автоматизованих інформаційних бібліотечних систем, $\epsilon$ ступінь стандартизації під час формування основних полів бібліографічних записів, у тому числі пошукових полів.

В умовах окремих бібліотек завдання стандартизації розв'язується шляхом створення різноманітних довідників, що містять нормативну інформацію,
\end{abstract}


використовувану в певній бібліотеці, - нормативні бази даних. Для багатьох книгозбірень такими нормативними базами слугують бази авторитетних файлів. Здійснення роботи зі стандартизації під час формування бібліографічних записів називається авторитетним контролем (АК).

Виникнення спеціальної інформаційної технології ,авторитетний контроль” викликано необхідністю дотримання принципу уніфікації заголовків бібліографічних записів. Уніфіковані дані і посилання на них записуються в машинній формі й інформаційно пов’язуються з бібліографічними записами, у яких використовують ці уніфіковані записи. Кожний бібліографічний запис містить кілька пошукових елементів і тому пов'язаний з такою кількістю авторитетних записів, якою є кількість пошукових елементів і які необхідно перевірити за допомогою АК. Під час формування електронного каталогу (ЕК) насамперед мають бути створені авторитетні записи, а потім бібліографічні записи, які охоплюють пошукові елементи, зазначені в авторитетних записах [5].

Потреба в уніфікації заголовків бібліографічних записів зумовила створення спеціальної інформаційної технології ії забезпечення. Такою технологією і став АК, а традиційні картотеки авторів (індивідуальних і колективних, тобто імена осіб і назв установ та організацій), на початку 70-х років отримали назву „авторитетні”, тобто офіційні [7].

Автоматизація каталогізаційних процесів зумовила ведення авторитетного контролю в ЕК, з яким пов’язане створення сучасних авторитетних файлів (АФ). Що розуміється під назвою АФ? Переважно це файл, який містить важливу інформацію про індивідуального автора, колективного автора або предметну рубрику. Він $\epsilon$ вагомим інструментом каталогізаторів не тільки під час описування відповідних документів, а й, що більш важливо, а й пошуку необхідного документа. Авторитетні дані - це нормовані, контрольовані елементи пошуку бібліографічних записів, які позначені не кодами, а лексичними засобами мов [2].

Практика ведення авторитетних файлів в Україні і за кордоном показує різноманітність підходів до змісту авторитетних записів, форматів представлення даних у машиночитній формі, правил каталогізації $[4,5]$.

У рамках АК зарубіжні автори виокремлюють такий компонент, як авторитетна робота (authoritywork), тобто інтелектуально-нормативна робота [8, 9]. У результаті 
авторитетної роботи, яка передбачає вибір авторитетного заголовка, запис його варіантів і фіксацію зв'язків, отримують авторитетний запис, вихідним елементом якого $є$ авторитетний заголовок. Крім авторитетного заголовка запис може містити варіанти заголовка, посилання, довідки, примітки тощо. Авторитетний заголовок $\epsilon$ уніфікованою формою імені, предмета чи назви, яка використовується як точка доступу до бібліографічного запису. Авторитетний заголовок є вихідним елементом запису, який беруть до уваги в абетковому впорядкуванні записів. Сукупність авторитетних записів утворює авторитетний файл [1].

Між авторитетним файлом і бібліографічним файлом встановлюється автоматичний зв’язок. За наявності необхідного заголовка в АФ каталогізатор копіює його в бібліографічний запис; у разі відсутності необхідного заголовка в АФ каталогізатор створює нову авторитетну форму заголовка в АФ і копіює його. Водночас кожен новий заголовок проходить процедуру затвердження його як авторитетного.

У зв’язку з появою нових інформаційних технологій авторитетний контроль виокремлюється як самостійний елемент - один із технологічних процесів каталогізації.

Актуальність такої роботи обумовлена багатьма причинами, а саме:

- зростанням кількості автоматизованих інформаційних систем і постійним їх удосконаленням, насамперед електронних бібліотечних каталогів;

- необхідністю переведення інформації, накопиченої в бібліотеці, у машиночитну форму для підтримки електронного каталогу й організації віддаленого доступу до його баз даних (БД);

- необхідністю кооперування роботи у сфері авторитетного контролю для запобігання дублювання інформації в бібліотеках України, налагодження обміну записами на національному і міжнародному рівнях;

- процесами інтеграції і диференціації наукових і навчальних дисциплін та змінами у сфері організації науки.

Визначення змісту і структури авторитетних записів $є$ актуальним також за впровадження інформаційно-комунікаційних технологій (IКТ).

Фахівцями ДНПБ України імені В. О. Сухомлинського (далі - Бібліотека) у 2006 р. створено авторитетний файл „Колективні автори” (АФ „КА”). Тепер під час 
створення бібліографічного запису (БЗ) і за необхідності введення в БЗ колективного автора каталогізатор використовує АФ „КА”, здійснюючи так авторитетний контроль колективних авторів [4].

Водночас каталогізатор i бібліограф мають нагальну потребу відрізняти й ідентифікувати однойменних індивідуальних авторів, приводити до єдиної загальноприйнятої форми альтернативні форми імен того ж автора, а саме псевдоніми, транслітерації, варіанти формулювання тощо [1].

Під авторитетним контролем „Індивідуальні автори” розуміється процес відстеження різних форм імені автора і їх співвідношення, підтримання єдиних форм авторитетних заголовків, які визначають одну й ту ж особу, підтримання сталості і сумісності форми імені в заголовках бібліографічних записів на основі їх уніфікації із застосуванням електронно-обчислюваної техніки, контроль 3 послідовним дотриманням принципів, методик, інструкцій і правил 3 представлення пошукових ознак документа.

Основною метою такої роботи є створення АФ імен індивідуальних авторів, а також підготовка нормативно-інструктивних документів для створення авторитетних записів імен індивідуальних авторів.

Формування і ведення АФ „ІА” має забезпечувати уніфіковане зазначення відомостей про авторів, насамперед їхніх імен, повноту цих даних, а також створення єдиної системи посилань з відповідними поясненнями. АФ „ІА” створюється для гарантування якості наукового опрацювання документів, що надходять до Бібліотеки, дотримання єдності в роботі із заголовками, що містять імена індивідуальних авторів, пошуку видань певних авторів. База даних АФ „ІА” може використовуватися і як довідкова база для отримання додаткової інформації про авторів.

Ця робота здійснювалася в рамках наукового дослідження за темою „Теоретичні та науково-практичні аспекти створення інтегрованого інформаційного pecypcy в Державній науково-педагогічній бібліотеці України імені В. О. Сухомлинського" (наук. керівник - П. І. Рогова, канд. іст. наук., директор ДНПБ України імені В. О. Сухомлинського).

Мета статті - розкрити роль АФ „ІА” в уніфікуванні бібліографічних записів, уникненні помилок під час створення бібліографічних записів, а також у необхідності кооперування, тобто поступального об'єднання електронних каталогів бібліотек 
різних систем і відомств з різним програмним забезпеченням на основі створення єдиних нормативних файлів для якісного обміну даними [13]. Завдання статті полягає в тому, щоб показати необхідність створення авторитетних записів під час формування ЕК бібліотеки.

Методологічною основою дослідження $є$ праці вітчизняних i зарубіжних бібліотекознавців, бібліографознавців, книгознавців. Під час розроблення концепції створення i наповнення авторитетних записів в ДНПБ України імені В. О. Сухомлинського був узагальнений досвід провідних вітчизняних i закордонних бібліотек, передусім Росії.

Джерелами дослідження слугували: офіційні видання Національної академії наук України (НАН України), Національної академії педагогічних наук України (НАПН України) та інших галузевих академій наук України, офіційна інформація із сайтів, інших видань установ i організацій, матеріали довідкових видань (енциклопедій, довідників) [10, 11].

Функції бібліографа під час створення АФ „IA”:

- виділити й однозначно ідентифікувати визначені імена індивідуальних авторів;

- зібрати всі варіанти імені, встановивши при цьому нормативне ім'я, створене відповідно до правил каталогізації;

- визначити, за можливості, усі прийняті форми імені й установити між ними методологічні зв’язки, які опрацьовуються програмно;

- вказати додаткову інформацію про індивідуального автора, яка може бути корисною користувачеві, наприклад, місце роботи і посада на час створення авторитетного запису, наукові ступені автора, нагороди, звання тощо.

Отже, кожному індивідуальному автору відповідає не тільки нормативне ім’я, як це було раніше за словникового контролю, а й повний довідковий набір даних, занесений в один або декілька авторитетних записів.

База даних „ІА” ДНПБ України імені В. О. Сухомлинського є комп’ютерним файлом, який містить нормовані імена індивідуальних авторів. Вона почала створюватись у 2010 р. на базі АБІС „ІРБІС64” версія 2009.1). Зараз БД „ІА” створюється на базі АБІС „ІРБІС64” версія 2010.1. 
Процес створення і модернізації БД АФ „ІА” здійснювався у два етапи. На першому етапі занесено дані на індивідуальних авторів:

- академіків і членів-кореспондентів НАПН України;

- академіків і членів-кореспондентів НАН України (вибірково);

- директорів наукових установ НАПН України;

- міністрів освіти і науки України;

- видатних політичних діячів України XX-XXI ст.: президентів, прем'єрміністрів, голів Верховної Ради України, лідерів політичних партій і рухів тощо (вибірково);

- видатних діячів України в галузі освіти, культури, науки, релігії тощо (вибірково);

- педагогічних i науково-педагогічних працівників навчальних закладів України (вищих, загальноосвітніх, дошкільних, позашкільних) усіх рівнів акредитації (вибірково);

- працівників провідних бібліотек України і Росії (вибірково);

- науковців Державної науково-педагогічної бібліотеки України імені В. О. Сухомлинського.

Далі БД АФ „ІА” доповнюють новими або раніше невідомими іменами під час опрацювання нових надходжень до Бібліотеки. Водночас здійснюють бібліографічний аналіз документів, що опрацьовуються, у результаті якого встановлюється точна інформація про автора документа. Другий етап - це постійне відстеження й редагування запису в разі необхідності. Записи в БД АФ „ІА” формулюють українською мовою. Заголовок АФ „ІА” створюється мовою оригіналу видання. Якщо твір українського автора надруковано російською мовою, для полегшення пошуку й формування авторських комплексів ім’я в АФ „ІА” вводять українською мовою.

Нині авторитетна робота проводиться під час опрацювання нових надходжень, у майбутньому поповнення АФ „ІА” планується здійснювати також під час ретрокаталогізації фонду бібліотеки.

Із закладених у програму „ІРБІС64” полів для створення АФ „ІА” фахівцями ДНПБ України імені В. О. Сухомлинського використовуються декілька. Аналіз засвідчив, що заповнення інших полів (підполів) недоцільне, оскільки вони не задіяні в пошуку й не містять корисної інформації. 
Для уніфікації створення АФ „ІА” на базі АБІС „ІРБІС64” науковцями відділу наукового опрацювання й каталогізації документів ДНПБ України імені В. О. Сухомлинського розроблено інструкцію, що містить правила заповнення полів $\mathrm{i}$ підполів. В інструкції визначено список полів і підполів, необхідних для створення АФ „ІА”, розкрито їхній зміст і наведено приклади заповнення. Правила заповнення полів і підполів розроблено на основі чинних стандартів, нормативно-інструктивних і методичних документів 3 питань бібліографічного описування документів, формування заголовків БЗ (ДСТУ ГОСТ 7.80:2007 ССІБВС. Бібліографічний запис. Заголовок. Загальні вимоги та правила складання) і використання скорочень слів для створення записів українською, російською та іноземними мовами.

Згідно з інструкцією інформація в БД АФ „ІА” записується так:

- Поле 210 - Основне (прийняте) ім'я особи; у цьому полі використовують такі підполя:

- початковий елемент уведення (прізвище або ім'я особи);

- ініціали;

- розширення ініціалів;

- роль (інвертування ПІБ (прізвище, ім'я та по батькові) припустимо?));

- невід’ємна частина імені (вводиться в дужках); наприклад, О. Дюма (батько) чи О. Дюма (син);

- ідентифікуючі ознаки імені; підполе заповнюють, якщо особа є титулованою або має духовний сан (наприклад, князь, митрополит);

- римські цифри; підполе заповнюють, якщо біля імені автора подано династичний номер; династичний номер виражається порядковим числівником, який записують римськими цифрами; береться виключно з вбудованого словника (Іоан Павло II);

- д дати (вводяться відомості про роки життя або рік народження особи);

- графіка; із вбудованого словника обирають графіку: са -,,кирилиця" (українська, російська) або ba - „латинська” (англійська, польська та ін.);

- мова заголовка; підполе ідентифікує мову заголовка, якщо вона відрізняється від мови каталогізування; обирають із вбудованого словника: ukr (українська), rus (російська), eng (англійська) та ін.; 
- ознака введення імені особи; із вбудованого словника вибирають позначку „0”, якщо ім'я особи зазначене під особистим ім’ям, або позначку „1”, якщо ім’я особи зазначене під прізвищем;

- код відношення; із вбудованого словника вибирають код, який відповідає статусу особи, наприклад, 070 - автор; якщо у процесі створення Б3 у базі даних „Книги” під час заповнення поля 702 „Редактори, укладачі, композитори ...” відомості про особу зазначаються через $\boldsymbol{A U T H O R I T Y - \phi a и ̆ л ~ I A ” , ~ у ~ п і д п о л і ~ „ Ф у н к ц і я ” ~}$ поля 702 код відношення (автор - 070 із поля 210 АФ „ІА”) автоматично не відображається. У підполі „Функція” необхідно вручну вибрати потрібний код, наприклад ,,340 редкол. - редколегія”.

- Поле 910 - Місце роботи автора; у цьому полі використовують такі підполя:

- працює в даній установі; якщо особа на момент складання запису працює в Бібліотеці, ставиться позначка „Так”;

- місце роботи автора; вказується місце роботи особи та посада, яку вона займає на час складання запису.

- Поле 410 - Посилання типу „Див.” (варіантні (інші) форми імені особи.

Такі заголовки створюються в тому випадку, якщо існують варіантні (інші) форми написання імені особи. Для такого заголовка також складається свій авторитетний запис, у якому заповнюють такі ж поля й підполя, як і для основного (прийнятого) імені особи. Наприклад, Еворницький; основна форма - Яворницький).

- Поле 510 - Посилання типу „Див. також” (зв’язані прийняті форми імені особи).

Такі заголовки створюються, якщо у різні часи твори видавалися автором під різними прізвищами, іменами або псевдонімами. У цьому разі необхідно створювати в АФ окремі авторитетні записи на кожну (іншу) форму імені особи. Наприклад, Огіснко - інша форма імені особи Іларіон; Тобілевич - псевдонім КарпенкоКарий.

- Поле 710 - Зв'язані прийняті форми імені особи іншими мовами.

Якщо ім’я особи наводиться двома й більше мовами, у цьому полі створюються записи іншими мовами. Запис кожною мовою створюється в окремому рядку, подібно до записів у полі 210. Змінюються відомості у підполі „Графіка” та „Мова 
каталогізації’. Запис у цьому полі виводиться у словник індивідуальних авторів окремим рядком і може бути використаний для введення у процесі каталогізації.

- Поле 300 - Інформаційна примітка.

Вказують вчені ступені, наукові й почесні звання, відзнаки особи тощо (наприклад, академік НАПН України, доктор психологічних наук, професор).

- Поле 305 - Текстова посилальна примітка „Див. також”.

Це поле заповнюється для пояснення зв’язку між заголовком у полі 210 і зв’язаними заголовками у полі 510, якщо посилання „Див. також” не може бути адекватно сформоване зі змісту поля 510. Поле 305 використовується у записах для доповнення інформації поля 510. Це означає, що заголовки, наведені у підполях „1-й, 2-й, 3-й, 4-й, 5-й заголовок, до якого робиться посилання” поля 305, мають бути наведені у полі 510. Наприклад:

Поле 210: Вентцель Олена Сергіївна

Поле 510: Грекова Ірина

Поле 305 (1-й заголовок): під псевдонімом Грекова Ірина відома як автор творів художньої літератури.

Якщо заповнюється поле 305, у підполі „Код формування посилання” поля 510 потрібно зазначити блокування виведення посилання на екран (вибирається із вбудованого словника).

Наприклад:

е0 - Псевдонім автора з блокуванням виведення посилання на екран.

$\mathbf{f 0}$ - Справжнє ім’я автора з блокуванням виведення посилання на екран.

$\mathbf{z 0}$ - Інше ім’я автора з блокуванням виведення посилання на екран.

- Поле 801 - Джерело складання запису; у цьому полі використовують такі підполя:

○ країна (обирається із вбудованого словника);

○ установа; зазначають повну назву Бібліотеки, абревіатуру відділу та прізвище працівника, який створив запис;

○ дата введення або дата останнього опрацювання.

- Поле 810 - Джерело, у якому виявлено інформацію про заголовок.

Використовується для обгрунтування вибору заголовка. Поле множиме, повторюється для запису різних джерел, у яких виявлено інформацію. Перше 
входження у поле містить дані, на основі яких сформульовано заголовок. У повтореннях поля наводяться джерела і відомості з них, які дають іншу форму заголовка.

- Поле 835 - Інформація про вилучення прийнятого імені особи.

У підполі,,Текст примітки” вказується причина, з якої з АФ виключено даний авторитетний запис; у підполі „Заголовок, на який змінено вилучений” вказується нове (змінене) ім'я особи.

Під час створення бібліографічних записів в ЕК програма „ІРБІС64” дозволяє автоматично заносити інформацію в БЗ. Для цього необхідно скористатися полем „Введення через AUTHORITY-файл”, а далі - через навігатор і закладку „Словник”. У закладці „Словник” записи представлено за абеткою прізвищ індивідуальних авторів. Для пошуку і введення даних про того чи іншого автора слід набрати прізвище цього автора у вікні „Ключ”. Якщо прізвище цього автора є в АФ, його використовують у бібліографічному записі. Переваги такого підходу в тому, що перенесення даних 3 авторитетних файлів дозволяє заощадити час й уникнути помилок у процесі формування БЗ, які трапляються в разі ручного введення інформації. За відсутності назви в БД АФ „ІА” попередньо створюють авторитетний запис.

Наукова новизна роботи визначається такими результатами:

- здійснено авторитетний запис імен індивідуальних авторів - науковців системи НАПН України, НАН України, МОНмолодьспорт України тощо;

- виявлено сучасні тенденції розвитку АК у вітчизняних i зарубіжних бібліотеках;

- обгрунтовано методику створення авторитетних записів імен індивідуальних авторів на основі розроблених під час дослідження підходів, спеціалізації бібліотеки.

Практична цінність дослідження полягає в тому, що створений АФ „ІА” містить вивірені, уніфіковані дані (прізвище, ім'я та по батькові) про науковців НАН України, НАПН України та інших відомств і може використовуватися у створенні й веденні ЕК ДНПБ України імені В. О. Сухомлинського, а також як електронний довідник під час виконання запитів користувачів. У перспективі авторитетний файл 
ДНПБ України імені В. О. Сухомлинського може бути використаний $\quad$ у корпоратизації, а також у створенні українського національного АФ.

Створюючи БД АФ „ІА”, фахівці Бібліотеки стикалися з певними труднощами. Наприклад, у роботі з програмою ІРБІС64 версії 2009.1 під час заповнення підполя „Розкриття ініціалів особистого імені” поля 210 „Основне (прийняте) ім’я особи” зникав зі словника збережений в БД попередній запис на особу, залишаючи тільки номер MFN. Після установки версії 2010.1 цей недолік не спостерігається і БД АФ „ІА” успішно поповнюється.

Результатом створення АФ „ІА” може бути інтеграція АК бібліографічних записів в інформаційні системи наукових і педагогічних бібліотек України. У міру накопичення інформації в БД АФ „ІА” передбачається відкрити зазначену БД для використання іншими бібліотеками України. АФ „ІА” є унікальним інформаційним продуктом, який допомагає здійснювати релевантний пошук у базах даних електронного каталогу. Він може бути корисний не тільки для працівників бібліотек, а й для інших інформаційних систем.

Комплексна автоматизація бібліотек дозволить організувати обмін авторитетними даними i налагодити АК на регіональному, національному та міжнародному рівнях.

Розподілена система авторитетних файлів і авторитетного контролю дає можливість каталогізатору у процесі каталогізації документів заходити в авторитетні файли для уточнення інформації, а також отримувати довідкову інформацію. В умовах корпоративної каталогізації використання авторитетних заголовків дозволить знизити трудовитрати і підвищити економічну ефективність. У перспективі продовження роботи у цьому напрямку в ДНПБ України імені В. О. Сухомлинського передбачає створення авторитетного файлу „Предметні рубрики”.

\section{Список використаних джерел}

1. Антоненко I. П. Авторитетний контроль бібліографічних записів / I. Антоненко // Бібліотечний вісник. - 1995. - № 4. - С. 1-4.

2. Жлобинская O. Особенности авторитетной работы. Роль и место авторитетных файлов в машиночитаемой каталогизации / Ольга Жлобинская, Татьяна Масхулия, Юлия Селиванова // Библиотечное дело. - 2005. - № 6. - С. 25-26. 
3. Ильина С. В. Проблемы создания национальных баз данных авторитетных записей [Электронный pecypc] / С. В. Ильина. - Режим доступа : www.nlb.by/html/news2005/. - Заглавие с экрана.

4. Коваленко С. Г. Створення авторитетного файлу „Колективний автор” на базі АБІС „ІРБІС” для електронного каталогу Державної науково-педагогічної бібліотеки України імені В. О. Сухомлинського / С. Г. Коваленко, Р. П. Гаврилюк : [Електронний ресурс] // Інформаційні технології і засоби навчання. - 2009. - Вип. 2 (10). - Режим доступу : http://www.nbuv.gov.ua/e-jornals/ITZN/emg.html. - Назва 3 екрана.

5. Лавренова О. А. Банки нормативных (авторитетных) записей / О. А. Лавренова // Библиотековедение. - 1997. - № 2. - С. 40-46.

6. Лонюк О. Т. Авторитетний файл как информационный ресурс / О. Т.Лонюк [Электронный ресурс] / О. Т. Лонюк - Режим доступа : http://lib.krgtu.ru/irbis/long.doc. - Заглавие с экрана.

7. Лупінос М. Авторитетний контроль / М. Лупінос // Бібліотечна планета. 2007. - № 1. - C. 33-37.

8. Муктепавел А. В. Авторитетный контроль: теоретические и исторические аспекты / А. В. Муктепавел // Предметный поиск в традиционных и нетрадиционных ИПС : сб. науч. тр. - СПб, 2000. - Вып. 14. - С. 42-51.

9. Муктепавел А. В. Современное понимание авторитетного контроля и его исторические предпосылки / А. В. Муктепавел // Предметный поиск в традиционных и нетрадиционных ИПС : сб. науч. тр. - СПб, 1999. - Вып. 13. - С. 176-194.

10. Педагогічний словник / АПН України. Ін-т педагогіки ; за ред. Ярмаченка М. Д.; редкол.: М. Д. Ярмаченко (кер.), І. Я. Зязюн та ін. - К. : Педагогічна думка, 2001. - 516 с.

11. Універсальний словник-енциклопедія / кер. проекту Олександра Коваль; ред. рада : Мирослав Попович (голова), Іван Дзюба, Неллі Корнієнко та ін. - 2-ге вид., допов. - К. : Львів : ПВП „Всеувито”, ЛДКФ „Атлас”, 2001. - 1575 с. - ISBN 960-520015-1.

12. Фронкин $A$. В. Технология создания авторитетних и нормативных файлов в рамках корпоративной библиотечной системы Тверского района [Электронный 
pecypc] / А. В. Фронкин. - Режим доступа : http://corbis.library.tver.ru/cbs-055.htm . Заглавие с экрана.

13. Юрченко Я. Г. Авторитетный контроль как важнейший элемент интеграции [Электронный ресурс] / Юрченко Янина Геннадьевна. - Режим доступа : http://www.kemrsl.ru/documents/founds/vip2/vip2.5.htm. - Заглавие с экрана.

\section{СОЗДАНИЕ АВТОРИТЕТНОГО ФАЙЛА „ИНДИВИДУАЛЬНЫЕ АВТОРЫ” НА БАЗЕ АБИС „ИРБИС” ДЛЯ ЭЛЕКТРОННОГО КАТАЛОГА ГОСУДАРСТВЕННОЙ НАУЧНО-ПЕДАГОГИЧЕСКОЙ БИБЛИОТЕКИ УКРАИНЫ ИМЕНИ В. А. СУХОМЛИНСКОГО}

Коваленко Светлана Георгиевна, научный сотрудник Государственной научнопедагогической библиотеки Украины имени В.А. Сухомлинского, г. Киев, e-mail: skovalenko@yandex.ru

\section{Аннотация}

Степень стандартизации при формировании основных полей библиографических записей, в том числе поисковых полей, является одним из основных показателей качества массивов библиографической информации. В условиях отдельных библиотек задание стандартизации решается путем создания различных справочников, которые вмещают в себя нормативную информацию, используемую в данной библиотеке - нормативные базы данных. Для большинства библиотек такими нормативными базами служат базы авторитетных файлов. Проведение роботы по стандартизации при формировании библиографических записей называется авторитетным контролем.

В статье освещен вопрос создания авторитетных файлов для электронного каталога Государственной научно-педагогической библиотеки Украины им. В. А. Сухомлинского, уточнено понятие „авторитетный контроль”, раскрыта технология создания авторитетного файла „Индивидуальные авторы”.

Ключевые слова: электронные каталоги, авторитетные файлы, индивидуальные авторы, библиотеки, информационные ресурсы, библиотечные каталоги, авторитетные записи. 


\section{CREATING AUTHORITY FILE "INDIVIDUAL AUTHORS" BASED ABIS "IRBIS"FOR E-CATALOG OF V. SUKHOMLYNSKYI STATE SCIENTIFIC AND PEDAGOGICAL LIBRARY OF UKRAINE}

Svitlana H. Kovalenko, researcher of V. Sukhomlynskyi State Scientific and Pedagogical Library of Ukraine, Kyiv, e-mail: skovalenko@yandex.ru

\section{Resume}

The level of standardization at forming of the basic fields of bibliographic records, including the searching fields, is one of basic indexes of quality of arrays of bibliographic information. In the conditions of separate libraries the task of standardization is solved by creation of various reference books that contain the normative information used in a certain library. They are called normative databases. Such normative bases are authoritative files for many libraries. Realization of work from standardization at forming of bibliographic records is named authoritative control. Execution of work on standardization in the formation of bibliographic records is named authoritative control.

The article highlights the issue of the creation of authoritative files for e-catalog in V. Sukhomlynskyi State Scientific and Pedagogical Library of Ukraine, clarifies the concept of "authoritative control", disclose the technology to create a series of authoritative file "Individual authors".

Keywords: electronic catalogs, authority files, individual authors, libraries, information resources, library catalogs, authoritative records. 